\title{
JARINGAN KOMUNIKASI ORGANISASI MASYARAKAT DALAM PEMBANGUNAN
}

\section{COMMUNITY ORGANIZATION COMMUNICATION NETWORK IN DEVELOPMENT}

\author{
M Luthfie ${ }^{1 a}$ \\ 1 Fakultas Ilmu Sosial dan Ilmu Politik, Universitas Djuanda Bogor, Jl. Tol Ciawi No. 1 \\ Kotak Pos 35 Ciawi Bogor 16720 \\ a Korespondensi: Muhammad Luthfie,Email: mluthfie@unida.ac.id \\ (Diterima: 20-12-2017; Ditelaah: 21-12-2017; Disetujui: 27-02-2018)
}

\begin{abstract}
This study analyzes the role of Muhammadiyah in rural development. To introduce its existence and support its participation in development in the village of Plompong, Muhammadiyah Plompong as a community organization has formed and expanded its communication network with relevant parties, especially with the Village Government of Plompong. This is very reasonable, because organizational dynamics will not be separated from the communication of external organizations. Organizational systems consisting of many subsystems are built through the exchange of energy, information and meaning through networks and communication channels. Communication networks can be done spontaneously or planned, while channels are usually determined and restricted. To describe the Muhammadiyah Plompong communication network in order to introduce its existence and its participation in village development in Plompong Village, it is necessary to identify the communication interaction process that took place between Muhammadiyah Plompong and related parties to form a communication network. The purpose of the study was to identify and then describe the communication structure and the communication interaction process that took place between Muhammadiyah Plompong and related parties to form a communication network. Research uses a qualitative approach with data collection techniques through observation, in depth interviews, and focus group discussions. The results showed that the communication structure and Muhammadiyah communication networks had been able to create harmony and access of the organization in the development of villages in Plompong Village.
\end{abstract}

Keywords: communication structure, communication network, communication channel.

\begin{abstract}
ABSTRAK
Penelitian ini menganalisis peran Muhammadiyah dalam pembangunan desa. Untuk memperkenalkan eksistensinya dan mendukung partisipasinya dalam pembangunan di Desa Plompong, Muhammadiyah Plompong sebagai organisasi masyarakat telah membentuk dan memperluas jaringan komunikasi dengan pihak-pihak terkait, terutama dengan Pemerintah Desa Plompong. Hal ini sangat beralasan, karena dinamika organisasi tidak akan terlepas dari komunikasi organisasi eksternal. Sistem-sistem organisasi yang terdiri dari banyak sub sistem dibangun melalui pertukaran energi, informasi dan makna melalui jaringan dan saluran komunikasi. Jaringan komunikasi (communication network) dapat dilakukan secara spontan atau terencana, sementara saluran biasanya ditentukan dan dibatasi. Untuk menggambarkan jaringan komunikasi Muhammadiyah Plompong dalam rangka memperkenalkan eksistensinya dan partisipasinya dalam pembangunan desa di Desa Plompong, perlu dilakukan identifikasi proses interaksi komunikasi yang terjadi antara Muhammadiyah Plompong dan pihak-pihak yang terkait sehingga membentuk jaringan komunikasi. Tujuan penelitian adalah untuk mengidentifikasi kemudian mendeskripsikan
\end{abstract}


struktur komunikasi dan proses interaksi komunikasi yang terjadi antara Muhammadiyah Plompong dan pihak-pihak yang terkait sehingga membentuk jaringan komunikasi. Penelitian menggunakan pendekatan kualitatif dengan teknik pengumpulan data melalui observasi, indepth interview, dan focus group discussion. Hasil penelitian menunjukkan bahwa struktur komunikasi dan jaringan komunikasi Muhammadiyah telah mampu menciptakan harmonisasi dan akses organisasinya dalam pembangunan desa di Desa Plompong.

Kata kunci: struktur komunikasi, jaringan komunikasi, saluran komunikasi.

Luthfie, M. 2018. Jaringan Komunikasi Organisasi Masyarakat dalam Pembangunan. Jurnal Sosial Humaniora 9(1): 17-33.

\section{PENDAHULUAN}

Publikasi tentang keberadaan atau eksistensi dan rencana terlibat dalam interaksi komunikasi yang lebih luas, sangat penting dilakukan oleh organisasi masyarakat dalam kegiatan-kegiatan yang ada, termasuk dalam pembangunan desa. Todo et al (2011) dalam hasil penelitiannya, menyatakan jaringan komunikasi yang merupakan jaringan sosial sering didasarkan pada promosi aliran pengetahuan, pertemuan dan sebaliknya jaringan komunikasi tidak akan terbentuk tanpa ada pertemuan, hal ini menunjukan pentingnya tatap muka dalam difusi pengetahuan. Selanjutnya Todo et al juga menjelaskan bahwa beberapa aspek lain seperti agama dan etnis adalah aspek penting terbentuknya jaringan sosial di dalam masyarakat.

Jaringan penting dalam mengamati perilaku manusia melalui struktur komunikasi dalam suatu sistem (Rogers \& Kincaid 1981) dan menggambarkan tugastugas penting karena jaringan menghubungkan interpersonal atau individu atau antar organisasi dalam suatu sistem (Harris \& Nelson 2008). Efektivitas komunikasi organisasi dalam jaringan dapat ditentukan dari derajat hubungan dan kualitas hubungan yang terjadi dalam jaringan (Rogers \& Kincaid 1981). Pada jaringan komunikasi, aktor-aktor baik idividual, group atau organisasi terhubungkan melalui interaksi sosial seperti memberikan saran, berbagi pengetahuan dan aliansi.

Kedudukan pemuka pendapat (opinion leader) diakui sangat penting dalam jaringan komunikasi terutama untuk mewujudkan difusi inovasi. Pemuka pendapat (opinion leader) memainkan peranan kunci untuk mengevaluasi inovasi, menjaga komunikasi antar jaringan, memfasilitasi kesempatan untuk mendapatkan program, pelatihan dan menciptakan serta mempertahankan hubungan dengan organisasi eksternal. Pemimpin opini diidentifikasi sebagai sumber informasi dan inovasi untuk anggota komunitas dan pemimpin opini sangat terlibat aktif dalam mengevaluasi hasil-hasil inovasi yang diterapkan dalam komunitasnya, mempertimbangkan apakah inovasi tersebut sesuai bagi rekan-rekannya dan juga mempertimbangkan kondisi sosial, ekonomi dan lingkungan yang sangat mempengaruhi proses keputusan mereka. Di lingkungan Muhammadiyah Plompong, pimpinan Ranting terutama ketuanya akan menjadi opinion leader sekaligus sentral individu yang memainkan peran sebagai perancang atau pengatur jaringan komunikasi organisasi internal maupun eksternal.

Rumusan masalah penelitian adalah bagaimana struktur komunikasi dan proses interaksi komunikasi yang terjadi antara Muhammadiyah Plompong dan pihak-pihak yang terkait sehingga membentuk jaringan komunikasi. Berdasarkan rumusan tersebut, maka tujuan penelitian adalah 
mengidentifikasi dan menganalisis struktur komunikasi dan proses interaksi komunikasi antara Muhammadiyah Plompong dan pihak-pihak yang terkait hingga membentuk jaringan komunikasi yang positif.

\section{MATERI DAN METODE}

\section{Kerangka Teoretis Penelitian}

Setelah memahami berbagai teori tentang jaringan komunikasi (Rogers \& Kincaid 1981, Monge \& Contractor 2003, Harris dan Nelson 2008), maka struktur jaringan komunikasi Muhammadiyah Plompong membentuk kepada jaringan yang menghubungkan proses komunikasi antara Muhammadiyah Plompong dengan Anggota Organisasi subyek, Muhammadiyah dengan Pemerintah Desa Plompong, Muhammadiyah dengan Organisasi Masyarakat lainnya terutama NU, dan Muhammadiyah dengan warga di lingkungan lembaga pendidikan Muhammadiyah Plompong. Jaringan komunikasi Muhammadiyah Plompong pada analisisnya terkait dengan sosiogram dan indikator jaringan yaitu densitas dan sentralitas.

Sosiogram, adalah ilustrasi hubungan "siapa berinteraksi dengan siapa" atau gambaran pola komunikasi dalam suatu jaringan sosial (Rogers \& Kincaid 1981). Densitas adalah gambaran keterhubungan individu dalam suatu hubungan. Densitas pada jaringan biner adalah proporsi dari kemungkinan semua ikatan yang benarbenar hadir (Hanneman \& Ridle 2005). Sentralitas merupakan pengukuran terhadap jaringan komunikasi yang ditemukan dalam konsep sosiometric sebagai "star" yakni individu sebagai sumber informasi. Sentralitas terdiri dari sentralitas lokal (local centrality), sentralitas global (global centrality) dan sentralitas antara (betweeness centrality).

Penelitian terhadap jaringan komunikasi dilakukan melalui pendekatan kualitatif dengan pengumpulan data secara wawancara mendalam (indepth interview), Focus Group Discussion (FGD), dan studi dokumentasi. Tujuannya adalah untuk memperoleh deskripsi tentang struktur komunikasi dan proses interaksi komunikasi antara Muhammadiyah Plompong dan pihak-pihak yang terkait hingga membentuk jaringan komunikasi yang positif.

\section{Metode Penelitian}

Penelitian menggunakan pendekatan kualitatif yaitu berorientasi pada penjelasan data deskriptif dari obyek yang diteliti dengan mengarahkan pendekatanpendekatannya pada latar dan obyek tersebut secara alamiah dan holistik (utuh dan menyeluruh). Penelitian akan membangun gambaran yang kompleks dan holistik, menganalisis kata-kata, melaporkan pandangan informan secara terperinci dan melakukan penelitian dalam setting ilmiah.

Subyek penelitian dilakukan secara sengaja (purposive), berdasarkan temuan awal tentang jaringan komunikasi Ranting Muhammadiyah Plompong sebagai salah satu organisasi masyarakat yang berpartisipasi aktif dalam pembangunan desa di Desa Plompong. Penelitian pendahuluan sudah dilakukan pada bulan Mei - Juni tahun 2014. Pengambilan data kualitatif secara lengkap dilakukan pada bulan Oktober-Desember 2015.

Data yang dikumpulkan dalam penelitian adalah data primer dan sekunder Data primer diperoleh dari informan penelitian untuk mengetahui data-data yang terkait dengan rumusan masalah penelitian. Data sekunder diperoleh dari dokumen. Pengumpulan data dalam penelitian ini dilakukan dengan cara wawancara mendalam (indepth interview), Focus Group Discussion (FGD) dan studi dokumen. FGD dilakukan dengan mengundang 5 orang narasumber yang dipandang ahli dan mengetahui pokok masalah penelitian. Obyek penelitiannya, adalah tentang struktur komunikasi dan jaringan 
komunikasi yang ada di lingkungan Muhammadiyah Plompong.

\section{HASIL DAN PEMBAHASAN}

\section{Analisis Jaringan Komunikasi}

Analisis Jaringan Komunikasi adalah suatu metode penelitian untuk mengidentifikasikan struktur komunikasi dalam suatu sistem, di mana data hubungan mengenai arus komunikasi dianalisis dengan menggunakan beberapa tipe hubungan-hubungan korelasional sebagai unit-unit analisis. Tipe hubungan dalam Analisis Jaringan bukanlah analisis monadic (individu), tetapi dyadic (2 orang) atau lebih. Analisis jaringan komunikasi merupakan alat untuk mengidentifikasi jaringan komunikasi dalam suatu sistem (Rogers \& Kincaid 1981).

Peran seseorang dalam sebuah jaringan komunikasi bervariasi, dari yang sedikit sampai yang banyak. Peran-peran tersebut dapat diidentifikasi dalam berbagai nama, dan berbagai bentuk atau konfigurasi sosiometris, sesuai dengan kelaziman dan penamaan yang ada dalam model penelitian analisis jaringan komunikasi. Sekurangkurangnya ada 5 bentuk sosiometris; yaitu star, opinion leader, liaisons, bridges, atau isolated.

Star atau bintang adalah individu yang menempati posisi sentral dalam suatu jaringan, seseorang yang merupakan pemusatan jalur komunikasi dari beberapa orang. Opinion leader adalah seorang pemuka pendapat dan agen pembaharu yang relatif sering dapat mempengaruhi sikap dan tingkah laku orang lain untuk bertindak dalam cara tertentu secara informal. Liaisons atau penghubung adalah seorang individu yang menghubungkan dua klik atau lebih dalam suatu sistem, namun ia tidak menjadi anggota klik manapun. Bridge adalah jembatan atau seorang individu yang menghubungkan dua klik atau lebih dalam suatu sistem, dan ia menjadi anggota dari salah satu klik. Isolated atau pemencil adalah individu yang berada dalam lingkungan suatu sistem, tetapi tidak menjadi anggota dalam suatu sistem atau individu yang tidak terlibat dalam jaringan komunikasi (Rogers \& Kincaid 1981). Satu lagi adalah Penjaga pintu (gatekeeper) yaitu seseorang yang berada dalam suatu struktur jaringan komunikasi yang memungkinkan dia mengontrol arus informasi.

Pada analisis jaringan komunikasi ini, akan dikaji pula analisis jaringan komunikasi tingkat individu untuk melihat ukuran sentralitas. Pengukuran sentralitas bertujuan untuk mengidentifikasi posisi atau lokasi serta karakteristik aktor (node) dalam suatu jaringan komunikasi (Hatala 2006). Sentralitas juga dapat digunakan untuk mengukur keunggulan individu dalam sistem. Pengukuran sentralitas, meliputi sentralitas lokal, sentralitas global dan kebersamaan atau sentralitas antara (betweeness).

Pada penelitian, analisis terhadap jaringan komunikasi menghasilkan gambaran tentang struktur komunikasi yang terjalin di antara anggota Pimpinan Ranting Muhammadiyah Plompong, Pimpinan Ranting Muhammadiyah dengan anggota persyarikatan, Pimpinan Ranting Muhammadiyah dengan Aparat Pemerintahan Desa Plompong, dan Pimpinan Ranting Muhammadiyah dengan Pimpinan organisasi masyarakat lainnya di Desa Plompong. Analisisnya akan menghasilkan sosiogram, yaitu ilustrasi hubungan "siapa berinteraksi dengan siapa" atau gambaran pola komunikasi dalam suatu jaringan sosial (Rogers \& Kincaid 1981).

Pimpinan Ranting Muhammadiyah Desa Plompong membentuk jaringan komunikasi sebagai upaya mendesiminasi informasi eksistensi persyarikatan dan amal-amal usahanya. Jaringan komunikasi yang terbentuk merupakan bentuk interaksi aktor-aktor atau pihak-pihak yang terkait di dalamnya yang menunjukkan perilaku komunikasi mereka dalam memberi, menerima dan menyebarluaskan sebuah informasi. Analisis terhadap jaringan 
komunikasi menghasilkan sosiogram yang menggambarkan struktur komunikasi yang terjalin di lingkungan komunikasi Ranting Muhammadiyah Plompong. Prosesnya menunjukkan siapa berkomunikasi dengan siapa serta bagaimana suatu informasi terdistribusi. Selain itu, memperlihatkan gambaran siapa saja yang terjangkau oleh informasi, bagaimana informasi terdistribusi ke semua anggota sistem (kelompok) dan struktur jaringan komunikasi yang terbentuk serta bagaimana peran-peran dari aktor-aktor atau pihakpihak dalam struktur jaringan komunikasi tersebut.

Pada prosesnya, jaringan komunikasi di lingkungan Ranting Muhammadiyah Plompong sendiri bervariasi, dari peran yang sedikit sampai yang banyak. Peranperan tersebut dapat diidentifikasi dalam berbagai nama, dan berbagai bentuk atau konfigurasi sosiometris, sesuai dengan kelaziman dan penamaan yang ada dalam model penelitian analisis jaringan komunikasi. Analisisnya berawal dari adanya posisi star yang diisi oleh Sesepuh Muhammadiyah (H Mahroni dan $\mathrm{H}$ Mu'min Thoif) yang eksis terutama pada masa-masa awal Ranting Muhammadiyah Plompong; tokoh-tokoh pimpinan Muhammadiyah Plompong (Wahibpudin dan Marzuki) yang berperan pada masa sekarang; pimpinan lembaga pendidikan Muhammadiyah Plompong dari tahun 2000-sekarang (Tohirin, Taufik, Solahudin Hernawan, M Taip Subandi, Sahroni, Aini Inayati, dan Umi Zuhanah); Pemerintah, terutama Kepala Desa Plompong (Fatoni); serta ketua NU Plompong (Bunyamin). Bridge adalah para pengurus yang mengelola humas organisasi atau tim-tim kerja yang ditugaskan untuk mengelola hubungan antar lembaga, dan tokoh-tokoh Desa Plompong, seperti sekretaris desa dan kepala-kepala dusun. Sedangkan Liaisons adalah anggota-anggota masyarakat desa, termasuk para siswa dan orang tua siswa di lembaga-lembaga pendidikan Muhammadiyah Plompong, yang sering dilibatkan dalam proses komunikasi dari kelompok-kelompok yang ada, tetapi mereka bukan anggota sistem dari kelompok-kelompok tersebut.

Untuk menentukan star dalam penelitian, tidak membutuhkan tindakan yang mendalam, sebab:

1. Tokoh-tokoh yang berpengaruh di internal dan eksternal Muhammadiyah Plompong dari awal pendiriannya sampai penelitian berlangsung masih ada dan mudah ditemui.

2. Tokoh-tokoh yang ditentukan sebagai star dipertimbangkan melalui sumbersumber data yang dimilikinya serta seringnya mereka dijadikan sumber informasi dan komunikasi Muhammadiyah Plompong.

Dari penelitian yang dilakukan, dari wilayah penelitian terkait dengan kajian jaringan komunikasi di masing-masing periode kepemimpinan Ranting Muhammadiyah Plompong, ada 13 orang informan yang menjadi star dengan posisi sentral (sentralitas), baik sentralitas lokal, sentralitas global, maupun sentralitas antara atau kebersamaan. Sepanjang sejarah Muhammadiyah Plompong, star dengan sentralitas lokal sekaligus sentralitas global pada penelitian di lingkungan internal Muhammadiyah Plompong terdapat pada diri H Mahroni, M Wahibpudin SAg MAg dan Marzuki SAg, di mana ketiganya pernah memegang atau sedang memegang amanah sebagai ketua ranting. Walaupun di Muhammadiyah tidak ada budaya menempatkan seseorang sebagai yang dimuliakan, tetapi dalam proses komunikasi internal Muhammadiyah Plompong atas dasar struktur organisasi atau tidak, ketiga orang itu selalu dijadikan tempat untuk bertanya dan meminta pertimbangan. Alasannya, seperti dikemukakan oleh Drs Tohirin MPd (wawancara tanggal 15 Oktober 2015) dilihat dari kapabilitas dan kedudukan sosial ketiganya. H Mahroni adalah sesepuh sekaligus pelaku dan ketua pertama Pimpinan Ranting Muhammadiyah Plompong yang mengetahui banyak sejarah Muhammadiyah di Desa Plompong, Wahibpudin adalah tokoh Muhammadiyah yang pernah menjadi ketua Pimpinan 
Ranting Muhammadiyah Plompong dan saat ini menjabat sebagai ketua Pimpinan Cabang Muhammadiyah Sirampog, serta Marzuki adalah ketua Pimpinan Ranting Muhammadiyah Plompong yang sedang berjalan. Sehingga alur jaringan komunikasi di internal Muhammadiyah Plompong (misalnya melalui studi jaringan komunikasi Pimpinan Ranting Muhammadiyah Plompong periode 2000-2015), akan berawal dari Marzuki kemudian diskusikan bersama Wahibpudin dan $\mathrm{H}$ Mahroni. Namun pada beberapa program, star (sentralitas individu) akan berpindah kepada pimpinan program/ amal usaha Organisasi subyek. Setelah itu, komunikasi akan berlanjut kepada pihak-pihak yang menjadi jembatan informasi untuk diteruskan kepada anggota Muhammadiyah maupun eksternal Organisasi subyek. Dari hasil FGD pada tanggal 20 Oktober 2015, diketahui perpindahan star disebabkan oleh:

1. Kelaziman organisasi. Dari struktur organisasi, maka ketua pimpinan Ranting Muhammadiyah akan menjadi star dalam organisasi.

2. Program, seperti program pembangunan sekolah. Star yang menjadi sentralitas akan terkait dengan pimpinan program, kemudian dikomunikasikan dengan star lain untuk meminta pertimbangan, dimusyawarahkan dengan pengelola sekolah, dan diimplementasikan kebijakannya kepada masyarakat luar.

3. Isu, misalnya terkait dengan isu-isu keagamaan atau kemasyarakatan, star dapat berpindah kepada sesepuh atau ketua Pimpinan Cabang Muhammadiyah Sirampog.

Pada beberapa program, jaringan komunikasi Muhammadiyah Plompong juga melibatkan opinion leader yang relatif sering dapat mempengaruhi sikap dan tingkah laku orang lain untuk bertindak dalam cara tertentu secara formal maupun informal. Para pemuka pendapat itu beragam latar belakangnya, ada yang berasal dari tokoh pemuda, tokoh agama, maupun pihak-pihak lainnya yang dalam jaringan komunikasi Muhammadiyah Plompong sering diajak berembuk. Keterlibatan pemuka-pemuka pendapat itu dalam komunikasi programprogram Muhammadiyah Plompong, umumnya didasarkan kepada pertimbangan-pertimbangan, antara lain muatan program yang baru pertama dijalankan atau kepada sifat program yang sensitif dan dapat memicu konflik dengan pihak lain.

Pada internal kepengurusan Ranting Muhammadiyah Plompong, maka ketua ranting selain menjadi opinion leader akan menjadi sentralitas individu sebagai star, yang pesannya disampaikan secara berantai kepada wakil ketua, kemudian disampaikan kepada sekretaris ranting untuk diarsipkan kebijakan-kebijakannya, lalu diteruskan kepada bidang-bidang atau divisi-divisi yang terkait dengan program. Hingga kepengurusan periode sekarang, bidangbidang yang aktif bergerak dan terlibat dalam jaringan komunikasi internal Ranting Muhammadiyah Plompong, adalah bidang tarjih, da'wah, pendidikan, dan bidang kerjasama sosial kemasyarakatan.

\section{Jaringan Komunikasi Muhammadiyah Plompong}

Analisis jaringan komunikasi pada penelitian, diarahkan untuk menganalisis jaringan komunikasi pada masa awal berdirinya Ranting Muhammadiyah di Desa Plompong, jaringan komunikasi di bidang tarjih dan da'wah, jaringan komunikasi di bidang pendidikan, dan jaringan komunikasi di bidang kerjasama sosial kemasyarakatan. Analisis jaringan komunikasi yang digunakan dalam penelitian, adalah untuk melihat (1) Struktur komunikasi, yakni pola hubungan dan peran individu di lingkungan program Muhammadiyah Plompong, (2) Jaringan Komunikasi, yakni gambaran interaksi antara aktor yang terlibat dalam proses komunikasi dan upaya memberikan informasi mengenai pengembangan eksistensi dan pengembangan program/ amal usaha Muhamadiyah di Plompong. Hasilnya akan memperlihatkan derajat 
sentralitas lokal (local centrality), derajat sentralitas global (global centrality), kebersamaan (betweenees) dan hubungan (connectedness).

Sentralitas lokal adalah derajat yang menunjukkan seberapa erat terhubungnya individu tertentu dalam lingkungan terdekat atau pertetanggaan mereka. Derajat ini menunjukkan jumlah hubungan maksimal yang mampu dibuat individu tertentu dengan individu lain yang berada dalam lingkungan terdekatnya. Sentralitas global adalah derajat yang menunjukkan berapa jarak yang harus dilalui oleh individu tertentu untuk menghubungi semua individu di dalam sistem. Derajat ini menunjukkan kemampuan individu untuk dapat menghubungi semua individu dalam sistem. Kebersamaan (betweenees) adalah frekuensi seorang individu dalam melakukan hubungan dengan pihak-pihak lainnya. Derajat ini menunjukkan kemampuan individu untuk menjadi perantara/penghubung antara satu aktor dengan aktor lain dalam suatu jaringan. Hubungan (connectedness) adalah derajat di mana anggota-anggota sistem berhubungan dengan anggota-anggota lain dalam sistem. Nilai connectedness diukur dengan membandingkan semua ikatan yang sedang terbentuk dengan kemungkinan hubungan yang mungkin terjadi. Konektivitas dapat menjadi ukuran yang berguna untuk mendapatkan pengertian tentang ketergantungan dan kerentanan individu (Hanneman \& Riddle 2005).

Pada konteks Muhammadiyah Plompong, jaringan komunikasi dikembangkan oleh para pimpinannya dengan tujuan memperluas interaksi melalui komunikasi, untuk memperoleh hasil yang baik dari program-program yang dikembangkan dan meraih tujuan-tujuan lainnya. Selain untuk memenuhi interaksi melalui komunikasi di lingkungan internal, jaringan komunikasi juga dikembangkan kepada pihak-pihak eksternal organisasi, terutama kepada pihak-pihak yang kedudukan dan kesepahaman pandangannya dapat menguntungkan Organisasi subyek.
Struktur komunikasi yang mewarnai jaringan komunikasi Muhammadiyah Plompong melibatkan pimpinan ranting dan anggota (internal), pemerintahan, dan organisasi-organisasi masyarakat lain seperti NU (eksternal).

Analisis jaringan komunikasi telah memberikan gambaran tentang siapa saja yang terjangkau oleh informasi, bagaimana informasi tersebar ke semua anggota sistem dan struktur jaringan komunikasi yang terbentuk serta bagaimana peran-peran anggota sistem dalam struktur jaringan komunikasi tersebut. Proses pembentukan jaringan komunikasi terjadi melalui interaksi yang dilakukan oleh pimpinan Ranting Muhammadiyah Plompong dengan anggota sistem lain dengan tujuan mendesiminasi informasi dari internal Muhammadiyah dan memenuhi kebutuhan informasi dari luar yang dibutuhkan untuk memperkuat eksistensi dan keberhasilan program Muhammadiyah di Desa Plompong. Jaringan komunikasi yang dilakukan sangat menentukan perubahan yang terjadi di lingkungan internal dan di lingkungan eksternal Muhammadiyah Plompong.

\section{Jaringan Komunikasi pada Periode Pertama}

Pada periode pertama kepemimpinan Ranting Muhammadiyah Plompong diwarnai oleh jaringan komunikasi yang materinya sebagian besar terkait dengan masalah khilafiyah (perbedaan prinsip ibadah/ fiqh). Sebagai gerakan pembaharuan di bidang keagamaan yang ingin membasmi tahyul, bid'ah dan churafat (TBC), Muhammadiyah harus bersinggungan dengan berbagai kelompok masyarakat, baik yang terorganisir ataupun tidak di Desa Plompong. Yang paling intensif dipicu oleh "peristiwa Perebutan Adzan Satu" di masjid desa tahun 1964. Sentralitas individu sebagai star diperankan oleh H Mahroni (HM), tokoh pendiri sekaligus ketua pertama di Ranting Muhammadiyah Plompong. Ia mengajak serta beberapa orang tokoh Muhammadiyah sebagai pemuka-pemuka pendapat; $\mathrm{H}$ 
Ma'mun Thoif, Rofi'i Syukri, M Said Kholil, M Fadhil Husaen, M Masroh Noer, Tohid Toha, M Mubari Muchtar, Muslim, Akyas, Abu Chaer, dan Sumar.

Jaringan komunikasi dalam internal organisasi (sentralitas lokal) sangat sering dilakukan, karena bertujuan untuk mempersiapkan pesan-pesan yang akan disampaikan dalam komunikasi atau dialog dengan pihak-pihak lain di Desa Plompong. Prinsip-prinsip keterbukaan tanpa menutup-nutupi adanya perbedaan, dijadikan landasan untuk melakukan tindakan komunikasi dengan pihak eksternal organisasi (Wahibpudin, wawancara tanggal 27 Oktober 2015). Benturan komunikasi yang sangat keras terjadi pada peristiwa Perebutan Adzan Satu di atas, di mana masing-masing pihak bersikukuh dengan keyakinan fiqh (pesan) masing-masing, yang membawa pihak-pihak yang berbeda pendapat berhadapan dengan solusi yang ditawarkan oleh pihak Kodim Brebes.

Komandan Kodim dalam analisis jaringan komunikasi penelitian digolongkan sebagai star sekaligus opinion leader karena berposisi sebagai pemuka pendapat yang berusaha mempengaruhi sikap dan tingkah laku tokoh-tokoh Muhammadiyah dan tokoh-tokoh organisasi masyarakat yang berseberangan untuk memperoleh solusi bersama. Komandan Kodim ini, pada akhirnya dapat meredam konflik dengan mendorong terjadinya kesepakatankesepakatan di antara pihak yang bertentangan dan mengawasi implementasinya.

Pada peristiwa Perebutan Adzan Satu tersebut, H Mahroni (HM), H Mu'min Thoif (HMT), Rofi'i Syukri (RS), M Said Kholil (MSK), dan M Fadhil Husaen (MFH) harus merasakan bermalam di Makodim Brebes dan disandera di sebuah pesantren oleh pihak yang berseberangan dengan prinsipprinsip Muhammadiyah (Royyani 2011). Tokoh Muhammadiyah yang menjadi star di klik Muhammadiyah itu, membawanya pula kepada derajat sentralitas global karena harus berhubungan dengan banyak pihak (klik-klik lain) dalam jaringan komunikasi, antara lain harus berdialog dengan Komandan Kodim dan dua orang stafnya, dan harus berdialog dengan tokoh-tokoh organisasi masyarakat dan pemuka-pemuka masyarakat dari klik lain (KH Maskur (KHM), Ustad Shohib (US), H Nurudin (HN), $\mathrm{H}$ Muhidin (HM), KH Idyas (KHI). Materi dialognya terutama menyangkut masalah khilafiyah yang bersumber dari perbedaan pandangan terhadap fiqh. Menurut $\mathrm{H}$ Mu'min Thoif (wawancara tanggal 3 November 2015) yang mendominasi komunikasi dalam dialog dengan pihakpihak eksternal tersebut adalah H Mahroni sebagai star dan dirinya sebagai orang kedua dalam tim. Anggota Muhammadiyah lainnya lebih banyak berfungsi sebagai penghubung dan kawan dalam berpikir. Demikian pula dengan di pihak NU, star nya adalah KH Maskur (KHM), selebihnya adalah pemuka pendapat atau kawan berpikir. Di pihak Kodim, Komandan Kodim sebagai star, dan selebihnya, yakni dua orang stafnya sebagai penghubung bridge.

Tabel 1 Identifikasi klik dalam jaringan komunikasi Muhammadiyah Plompong periode pertama

\begin{tabular}{llr}
\hline \multicolumn{1}{c}{ Klik } & \multicolumn{1}{c}{ Anggota Klik } & Jumlah \\
\hline I (Organisasi & HM, HMT, RS, & 5 \\
subyek) & MSK, MFH & \\
II (Ormas & KHM, US, HN, & 5 \\
lain) & HM, KHI & \\
III (Kodim) & K, S1, S2 & 3 \\
\hline
\end{tabular}

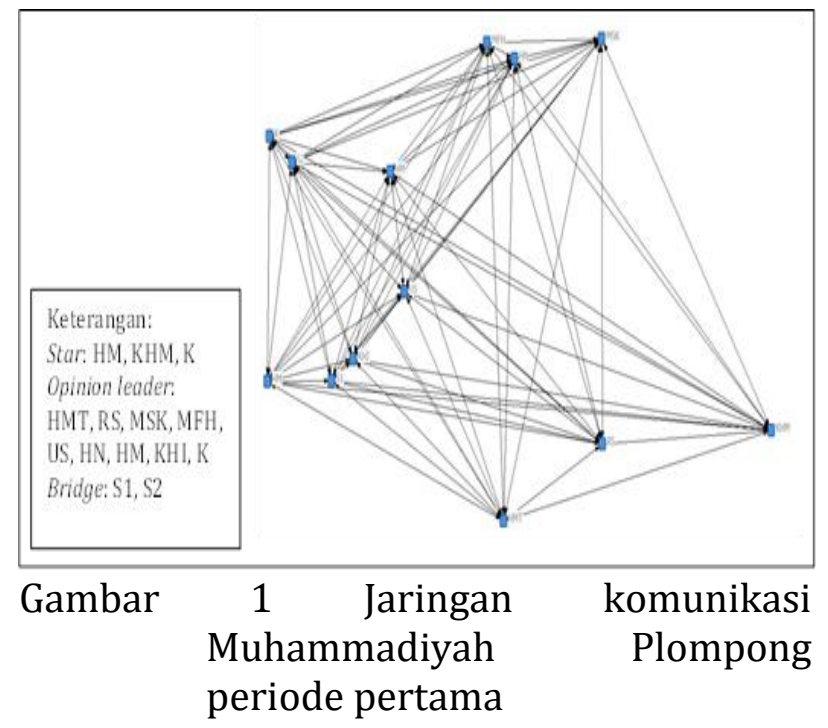


Melalui software Ucinet 6, maka jaringan komunikasi Ranting Muhammadiyah pada periode pertama dapat dilihat pada grafik sosiogram pada Gambar 1.

Peristiwa Perebutan Adzan Satu di Masdid Desa Plompong itu sendiri baru selesai secara bertahap pada periode kebangkitan Ranting Muhammadiyah Plompong (tahun 1981-1990) yang dilandasi oleh kompromi dan kesadaran organisasi masyarakat lain untuk menyerahkan pengelolaan ibadah di masjid desa kepada Organisasi subyek. Pertimbangannya, mayoritas warga Desa Plompong lebih menyetujui ritual keagamaan yang diselenggarakan oleh Muhammadiyah (terutama untuk shalat Jum'at dan dan shalat Shubuh) ketimbang dikelola oleh organisasi keagamaan lainnya. Muhammadiyah Plompong menerima kepercayaan itu, dan mengelola masjid desa termasuk pembangunan fisiknya hingga sekarang ini. Untuk menjaga keharmonisan, Muhammadiyah tetap melibatkan organisasi keagamaan lain dalam acara-acara yang diselenggarakan di masjid desa.

Secara garis besar, ada empat hal yang menjadi pesan Muhammadiyah pada dialogdialognya dengan pihak-pihak yang terlibat dalam jaringan komunikasi di atas. Pertama, Muhammadiyah menekankan prinsipprinsip keagamaan yang diterapkan dalam kehidupan anggota-anggotanya adalah sesuai dengan keputusan Tarjih Muhammadiyah yang mendasarkan diri kepada Al-qur'an dan sunnah Rasul. Kedua, Muhammadiyah adalah organisasi masyarakat di bidang sosial dan keagamaan, yang memiliki hak hidup di Republik Indonesia dan berhak berpartisipasi dalam pembangunan bangsa. Ketiga, Muhammadiyah adalah organisasi yang toleran terhadap perbedaan, dan siap bekerjasama untuk kemaslahatan umat. Dan keempat, Anggota Muhammadiyah di Desa Plompong adalah bagian dari kekerabatan masyarakat Desa Plompong, karena memiliki ikatan keluarga yang umumnya sama dengan pihak-pihak yang berseberangan.
Jaringan komunikasi Muhammadiyah Plompong pada periode pertama tersebut, dihubungkan oleh agen-agen yang menjadi bridge (humas dan staf). Komunikasinya menjadi multi hubungan antara Organisasi subyek, pemerintah (Kodim), organisasiorganisasi masyarakat termasuk NU, tokohtokoh masyarakat, dan pihak-pihak lainnya yang terlibat dalam jaringan. Jaringan komunikasi yang terjadi tidak menghasilkan kesamaan pandangan dari masalah-masalah yang diperdebatkan oleh masing-masing pihak (Muhammadiyah dan NU tetap pada keyakinannya) tetapi berhasil mewujudkan kompromi-kompromi dan ikatan-ikatan dalam isu bersama, seperti kepentingan pembangunan desa, pendidikan masyarakat, keamanan lingkungan, dan toleransi antar umat beragama.

Kesamaan pandangan dalam hal-hal di luar fiqh itu secara bertahap mewujudkan integrasi antara Muhammadiyah dan pihakpihak lainnya yang semula berseberangan, menghasilkan kompromi dan kerjasama dalam kegiatan-kegiatan pembangunan desa hingga kini. Elemen-elemen masyarakat desa itu bekerjasama dalam bidang keamanan, kesehatan, pendidikan, dan pertumbuhan ekonomi masyarakat desa (wawancara Fatoni, tanggal 28 Oktober 2015).

\section{Jaringan Komunikasi di Bidang Tarjih dan Da'wah}

Bidang tarjih, adalah bidang yang mengurusi pelaksanaan ibadah dan ritual di lingkungan Organisasi subyek. Keputusankeputusan Majlis Tarjih menjadi standar atau paremeter pelaksanaan ibadah seluruh anggota Organisasi subyek. Artinya, anggota-anggota Muhammadiyah wajib tunduk dan patuh dengan keputusan tarjih, yang keputusan-keputusannya ditetapkan setiap 5 tahun sekali bersamaan dengan diselenggarakannya Muktamar Organisasi subyek.

Keputusan Tarjih Muhammadiyah menjadi pedoman hidup warga Organisasi subyek, karena berisi seperangkat nilai dan norma Islami yang bersumber pada Al- 
Qur'an dan Sunnah untuk menjadi pola bagi tingkah laku warga Muhammadiyah dalam menjalani kehidupan sehari-hari, sehingga tercermin kepribadian Islami menuju terwujudnya masyarakat Islam yang sebenar-benarnya. Pedoman tersebut merupakan pedoman untuk menjalani kehidupan dalam lingkup pribadi, keluarga, bermasyarakat, berorganisasi, mengelola amal usaha, berbisnis, mengembangkan profesi, berbangsa dan bernegara, melestarikan lingkungan, mengembangkan ilmu pengetahuan dan teknologi, dan mengembangkan seni budaya yang menunjukkan perilaku uswah hasanah atau teladan yang baik (Abdurrahman \& Haedar 2003).

Komunikasi dan informasi tentang tarjih ini sangat intens dilakukan, sehingga materinya menjadi pesan-pesan yang sering disampaikan atau menjadi agenda dalam jaringan komunikasi Organisasi subyek. Di Ranting Muhammadiyah Plompong, penyebaran keputusan Tarjih ini dilakukan oleh Bidang Da'wah yang menyampaikan pesan-pesan da'wahnya melalui pengajian, khutbah dan ceramah-ceramah keagamaan. Materi keputusan tarjih, termasuk pokokpokok pesan dalam jaringan komunikasi Muhammadiyah Plompong. Pada periode kepemimpinan 2010-2015, Bidang Da'wah dalam fungsinya dibantu oleh pengelola Taman-taman Pendidikan Al-Qur'an (TPQ) Organisasi subyek, dan Pondok Pesantren Muhammadiyah Hj Nasikhah Maemanah.

Jaringan komunikasi di bidang tarjih dan da'wah ini lebih banyak ditujukan kepada anggota dan para pemimpin opini di internal Organisasi subyek, dengan maksud memperkuat pemahaman dan amalan sesuai keputusan tarjih Organisasi subyek. Pada beberapa acara seperti melalui pengajian umum, sebaran da'wah Muhammadiyah juga menghampiri masyarakat lain yang bukan anggota Organisasi subyek. Prosesnya dimulai dari ketua dan pimpinan harian Ranting Muhammadiyah Plompong (star) yang berhubungan dengan bidang da'wah (bridge). Pesannya menyampaikan pokokpokok kebijakan organisasi tentang Tauhid, peribadatan dan mu'amalah. Bidang da'wah selanjutnya menyampaikan kepada masingmasing pimpinan lembaga pendidikan dan pesantren. Jaringan komunikasi berlanjut kepada siswa-siswi atau santri-santri di lembaga masing-masing, termasuk kepada para orang tuanya (liaisons).

Media jaringan komunikasinya, adalah pengajian dan khutbah Jum'at, silaturami sekolah, dan melalui surat-surat edaran. Spanduk dan brosur dijadikan media komunikasi pada event-event tertentu, seperti pada pelaksanaan Shalat Idul Fitri dan Idul Adha. Pada bulan Ramadhan, kajian-kajian intensif tentang keislaman yang dilakukan ba'da shalat tarawih, menjadi media yang efektif pula untuk sosialisasi dan penjelasan tentang prinsipprinsip ibadah dalam sudut pandang Muhammadiyah kepada para jamaah, anggota dan simpatisan Organisasi subyek. Selain itu, ada training wajib yang harus diikuti oleh warga Organisasi subyek, seperti Baitul Arqam untuk para pengurus dan anggota Organisasi subyek, dan Darul Arqam untuk para mahasiswa dan siswa di lingkungan perguruan Organisasi subyek. Materi yang diberikan di samping aqidah, juga masalah keorganisasian dan kepemimpinan (leadership). Jaringan komunikasi di bidang tarjih dan da'wah tersebut, materinya seiring sejalan dengan jaringan komunikasi di bidang pendidikan. Ada target-target luaran (out put) yang sama-sama dituju oleh bidang pendidikan, seperti terciptanya peribadatan yang sesuai dengan keputusan tarjih Muhammadiyah dan pembinaan akhlakul karimah.

Proses jaringan komunikasi yang saling menguatkan ini, memang menjadi sistem koordinasi terpadu di lingkungan Persyarikatan Organisasi subyek, termasuk di Ranting Muhammadiyah Plompong. Sosiogramnya tersaji pada gambar 2 . 


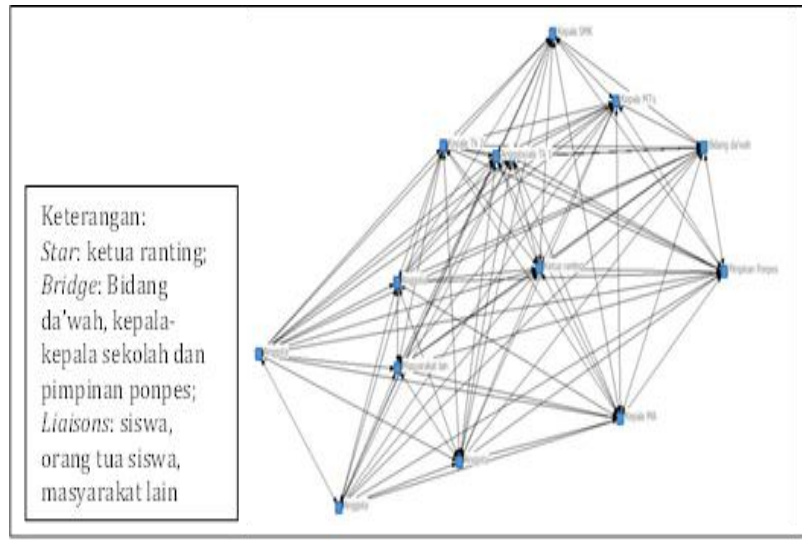

Gambar 2 Jaringan komunikasi Muhammadiyah bidang tarjih dan da'wah

\section{Jaringan Komunikasi di Bidang Pendidikan}

Bidang pendidikan, adalah bidang yang pesan-pesannya paling banyak berada dalam jaringan komunikasi Muhammadiyah Plompong. Agenda-agenda bidang pendidikan, sangat mewarnai jaringan komunikasi Organisasi subyek, apalagi Muhammadiyah memang dikenal sebagai organisasi kemasyarakatan yang piawai dalam menangani masalah pendidikan. Saat ini secara nasional Muhammadiyah telah memiliki 10.381 lembaga pendidikan, yang umumnya terakreditasi dengan baik sebagaimana disajikan pada tabel 2 (Data AUM 2016).

Tabel 2 Amal usaha Muhammadiyah di bidang pendidikan

\begin{tabular}{clc}
\hline No & \multicolumn{1}{c}{ Lembaga penidikan } & Jumlah \\
\hline 1 & TK/TPQ & 4.623 \\
2 & Sekolah Dasar (SD)/MI & 2.604 \\
& Sekolah Menengah Pertama & 1.772 \\
3 & (SMP)/MTs \\
& Sekolah Menengah Atas & 1.143 \\
4 & (SMA)/SMK/MA & \\
5 & Pondok Pesantren & 67 \\
& Perguruan tinggi Organisasi & 172 \\
6 & subyek $\quad$ Jumlah & 10.381 \\
\hline
\end{tabular}

Agenda-agenda bidang pendidikan yang seringkali menjadi pesan dalam jaringan komunikasi Muhammadiyah Plompong adalah penyempurnaan kurikulum pendidikan, akreditasi, pembangunan fasilitas pendidikan, dukungan wali siswa terhadap kegiatan belajar mengajar, dan lain sebagainya. Individu yang menempati posisi sentral (star) dalam jaringan komunikasi di bidang pendidikan, ditempati oleh para pimpinan lembaga pendidikan, walaupun dalam program-program tertentu posisinya bergeser kepada individu pimpinan program.

Pada prosesnya, kepala sekolah menyampaikan instruksi program kepada wakil-wakil kepala sekolah; urusan kurikulum kepada wakil kepala sekolah bidang kurikulum, urusan keuangan kepada wakil kepala sekolah bidang keuangan, dan urusan kesiswaan/ kerjasama kepada wakil kepala bidang kesiswaan. Selanjutnya bidang-bidang itu melakukan rapat dengan para guru, tata usaha dan OSIS (untuk bidang kesiswaan).

Selain untuk menginformasikan kebijakan sekolah, rapat-rapat sekolah diselenggarakan untuk memperoleh feedback, masukan atau kritikan yang membangun. Materi-materi rapat sebelumnya juga dikonsultasikan dulu kepada pimpinan ranting dan hasilnya dilaporkan pula kepada pimpinan ranting untuk dimintakan persetujuan. Pada bidang pendidikan, pimpinan ranting sering berada pada posisi opinion leader yang memberikan pertimbangan atau pendapat terhadap program-program yang akan dilaksanakan di lingkungan kerja Ranting Muhammadiyah Plompong. Pada beberapa program, star dalam bidang pendidikan ini berperan pula sebagai bridge yang menghubungkan antar anggota sistem jaringan. Kondisi seperti itu terjadi, jika anggota-anggota yang seharusnya menjadi penjembatan tidak aktif atau sedang berada pada posisi lain. Namun demikian, jaringan komunikasi tetap berproses dalam suatu sistem, yaitu struktur jaringan komunikasi Muhammadiyah Plompong.

Menurut data yang diperoleh dari hasil penelitian, segala urusan yang menyangkut bidang pendidikan selalu dibuat jaringan komunikasinya. Tujuannya, selain untuk 
menginformasikan kebijakan, juga dilakukan untuk memperoleh masukanmasukan untuk kesempurnaan pelaksanaan program (wawancara Drs Tohirin MPd, tanggal 15 Oktober 2015). Hasilnya memang menciptakan kebersamaan yang kuat di antara pimpinan ranting dan para pengelola sekolah, serta berhasil mendorong terwujudnya pembangunan amal-amal usaha Muhammadiyah yang secara umum bermanfaat untuk warga Desa Plompong.

Pada bidang pendidikan ini, starnya ada 6 individu, masing-masing adalah kepala sekolah/ kepala lembaga pendidikan dari 6 buah lembaga pendidikan yang dimiliki oleh Ranting Muhammadiyah Plompong, yang berhubungan melalui komunikasi dengan para staf dan dan panitia-panitia program (bridge). Para kepala sekolah selalu mengundang ketua ranting, sekretaris ranting dan bendahara ranting untuk dimintakan pertimbangan atau pendapat, termasuk dalam masalah rancangan keuangan. Selain itu dewan guru dan para orang tua siswa melalui POMG diajak juga untuk berembug dalam masalah programprogram sekolah. Di antara kepala sekolah pun memiliki hubungan koordinasi, untuk membicarakan berbagai kebijakan, terutama kebijakan yang datang dari pimpinan Organisasi subyek. Pada konteks ini, ketua ranting diposisikan sebagai opinion leader. Ilustrasi sosiogramnya pada Gambar 3.

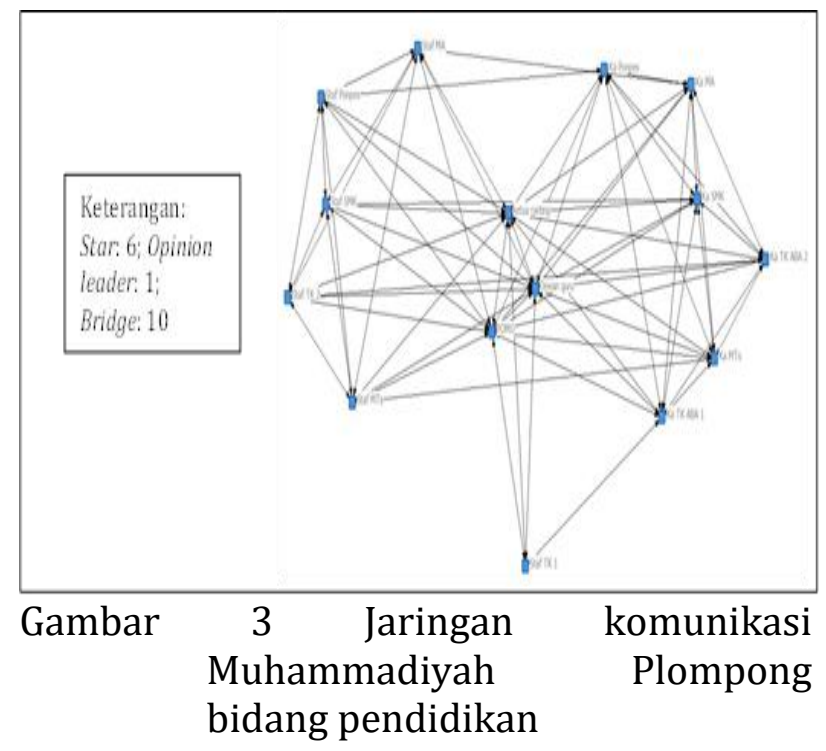

\section{Jaringan Komunikasi di Bidang Kerjasama Sosial Kemasyarakatan}

Bidang kerjasama sosial kemasyarakatan, memiliki fungsi untuk menjembatani komunikasi eksternal dan informasi kepada pihak desa dan organisasi-organisasi kemasyarakatan lainnya. Bidang ini adalah front terdepan Muhammadiyah di tengah masyarakat. Fungsi kehumasan menjadi cirinya, yang selalu bergerak saat Muhammadiyah Plompong membutuhkan dukungan dari pemerintahan desa atau yang di atasnya, dan organisasi-organisasi masyarakat lain yang ada di Desa Plompong, atau ketika Muhammadiyah Plompong akan berpartisipasi aktif dalam pembangunan desa di Desa Plompong. Bidang kehumasan dalam jaringan komunikasi Muhammadiyah Plompong menjadi bridge atau jembatan yang menghubungkan Muhammadiyah dengan pihak-pihak lainnya di Desa Plompong. Hingga tahun 2015, kinerjanya dinilai baik karena dapat turut mewujudkan harmonisasi di Desa Plompong dan mampu menyamakan pemahaman antar pihakpihak yang ada di Desa Plompong terhadap isu-isu atau kepentingan bersama, seperti pelaksanaan qurban Idul Adha terpadu, dan sebagainya.

Pada jaringan komunikasi di bidang kerjasama sosial kemasyarakatan star tetap dipegang oleh pimpinan Ranting Muhammadiyah Plompong, dalam hal ini ketua dan pimpinan harian lainnya. Posisinya menjadi sentralitas individu dalam sentralitas lokal dan global. Dari star prosesnya akan menuju bridge, yang mana penjembatan itu akan meneruskan komunikasi kepada para pengurus di bidang kerjasama sosial kemasyarakatan untuk dibahas dan didiskusikan, dan selanjutnya di sampaikan kepada pihak eksternal organisasi yang menjadi tujuan atau didesiminasikan kepada masyarakat luas. Pihak-pihak eksternal dalam penelitian, adalah aparat pemerintahan Desa Plompong, tokoh-tokoh masyarakat (opinion leader) dan tokoh-tokoh organisasi masyarakat lainnya. Musrebangdes, adalah salah satu medianya. Jika terdapat 
problematika di lapangan, tanpa melalui bridge, para pimpinan ranting yang menjadi star akan berkomunikasi langsung dengan para sesepuh atau penasehat ranting untuk meminta pendapat atau pertimbangannya (lihat gambar 4).

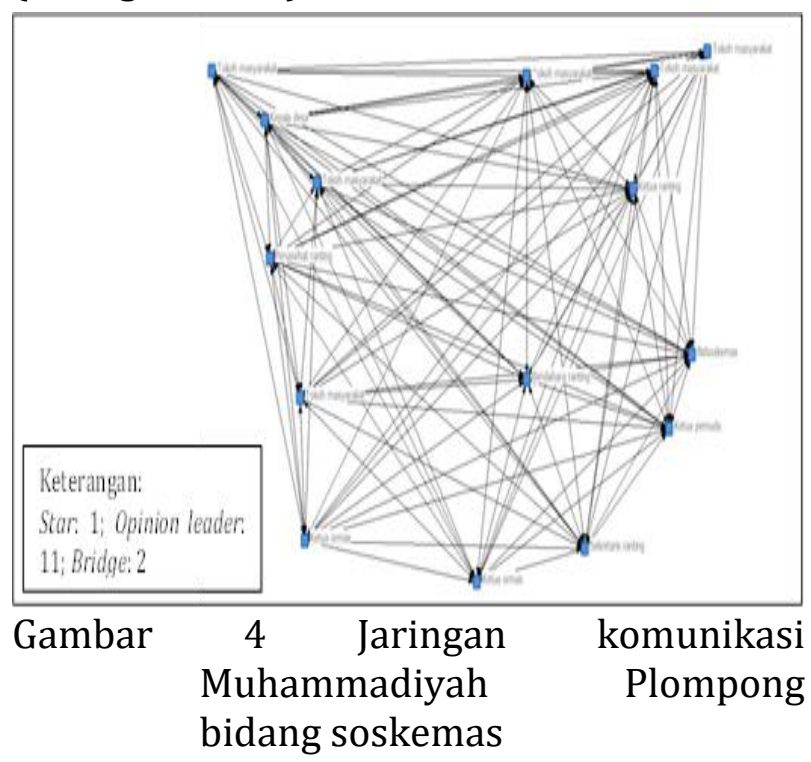

\section{Analisis Jaringan Komunikasi di Tingkat Individu}

Scott (2000), menyatakan derajat pengukuran sentralitas terdiri dari derajat beragam individu dalam sosiogram yang dapat menunjukkan seberapa baik terhubungnya individu tertentu dengan lingkungan mereka. Pengukuran Sentralitas bertujuan untuk mengidentifikasi posisi atau lokasi serta karakteristik aktor (node) dalam suatu jaringan komunikasi (Hatala 2006). Sentralitas lokal adalah derajat di mana seorang individu berhubungan dengan individu lain dalam sistem. Sentralitas lokal menunjukkan jumlah hubungan yang dapat dibuat individu dengan individu lain dalam sistem. Menurut Freeman dalam Scott (2000), sentralitas lokal dapat bersifat relatif. Hal ini akan menjadi sangat penting jika ukuran kelompok tidak sama. Sentralitas lokal memperhatikan keunggulan relatif individu yang menjadi star dalam hubungan lingkungan terdekat.

Nilai sentralitas lokal menunjukkan jumlah lingkungan yang mampu dibuat individu dalam lingkungan terdekatnya. Individu yang memiliki nilai sentralitas lokal terbesar disebut star (bintang) dan individu yang memiliki sentralitas lokal terkecil disebut isolate (pencilan). Dari pengukuran sentralitas akan diperoleh derajat beragam individu dalam sosiogram yang menunjukkan seberapa baik terhubungnya suatu individu dengan lingkungannya. Sentralitas juga dapat digunakan untuk mengukur keterunggulan individu dalam sistem. Pada penelitian, pengukuran sentralitas meliputi sentralitas lokal, sentralitas global, sentralitas antara atau kebersamaan (betweeneess) dan hubungan (connectedness) mengenai penyebaran komunikasi dan informasi Muhammadiyah di Desa Plompong.

\section{Sentralitas Lokal}

Sentralitas lokal adalah derajat yang menunjukkan seberapa baik terhubungnya individu tertentu dalam lingkungan terdekat atau pertetanggaan mereka. Derajat ini menunjukkan jumlah hubungan maksimal yang mampu dibuat individu tertentu dengan individu lain yang berada dalam lingkungan terdekatnya. Menurut Freeman dalam Scott (2000), local centrality atau sentralitas lokal memperhatikan keunggulan relatif individu yang menjadi star dalam hubungan pertetanggaan.

Keterhubungan aktor-aktor dalam jaringan komunikasi Muhammadiyah Plompong beragam. Ada yang mampu menghubungi banyak orang, karena kedudukan atau fungsinya, dan ada pula yang hanya dapat berhubungan dengan satu atau dua orang saja. Nilai sentralitas lokal tertinggi untuk semua topik pembicaraan dalam jaringan komunikasi dimiliki para pucuk pimpinan Ranting Muhammadiyah Plompong, khususnya ketua ranting. Sementara, individu yang memiliki nilai sentralitas lokal terendah merupakan individu yang memiliki kontak minimal dengan individu lain dalam lingkungan terdekatnya, seperti pada individu-individu yang hanya menjadi anggota pasif. Ia hanya berperan sebagai pencari informasi, bukan sebagai sumber informasi dalam lingkungan 
dengan artian, ia berperan sebagai yang menghubungi bukan yang dihubungi.

Kedudukan dan fungsi dalam organisasi atau sistem sosial yang berlaku, menjadi ukuran dari nilai sentralitas lokal dalam jaringan komunikasi Muhammadiyah Plompong. Individu dengan nilai sentralitas lokal rendah disebabkan oleh kurang terlibatnya mereka dalam jaringan komunikasi dan kurang tersentuh oleh pertukaran informasi yang berada di lingkungan mereka. Hal ini juga yang menyebabkan mereka enggan dijadikan sebagai sumber informasi atau pusat perhatian dalam interaksi sesama anggota sistem. Mereka hanya sampai pada titik yang menghubungkan, tetapi tidak untuk dihubungi dan tidak tidak terlibat dalam pembicaraan inti.

\section{Sentralitas Global}

Pengukuran sentralitas global diekspresikan dalam istilah "distance" di antara beragam individu. Global centrality atau sentralitas global memperhatikan keunggulan aktor dengan keseluruhan jaringan. Nilai sentralitas global menunjukkan jumlah ikatan yang seseorang butuhkan untuk menghubungi semua individu dalam jaringan. Sentralitas global dapat memberikan gambaran kemampuan akses individu di dalam sistem. Sentralitas global diperlukan sebagai bahan pertimbangan untuk memilih orang yang tepat sebagai kunci penyebar informasi. Semakin kecil nilai sentralitas global yang dimiliki individu maka semakin besar kemampuan individu tersebut untuk menghubungi semua orang dalam sistem (Scott 2000).

Pada sentralitas global dalam jaringan komunikasi Muhammadiyah Plompong, star harus mampu berhubungan dengan klik atau kelompok esternal. Ketua ranting Muhammadiyah Plompong harus berkomunikasi dengan ketua organisasi masyarakat lain dan aparat pemerintahan, khususnya Kepala Desa Plompong. Penelitian menunjukkan, sentralitas global yang ada pada jaringan komunikasi Muhammadiyah Plompong memiliki nilai sentralitas global yang rendah. Ukurannya, star dan anggota sistem lainnya mempunyai kemampuan lebih cepat untuk menghubungi individu lain dalam suatu sistem, dan lebih sedikit membutuhkan perantara (intermediaries). Pada konteks difusi informasi, individu dengan nilai sentralitas global rendah akan lebih dahulu menerima informasi daripada individu dengan nilai sentralitas global tinggi dalam suatu jaringan (Valente \& Foreman, 1998).

Rendahnya nilai sentralitas global anggota sistem dalam jaringan komunikasi Muhammadiyah disebabkan oleh sederhananya lembaga-lembaga atau individu-individu yang berinteraksi, sehingga siapa berkomunikasi dengan siapa cepat dapat diindentifikasi. Pada jaringan komunikasi Muhammadiyah Plompong, memang hanya ada tiga unsur besar di dalamnya, yaitu Muhammadiyah sendiri, Pimpinan NU, dan Pemerintahan Desa Plompong. Di Desa Plompong, ketiga kekuatan sosial itu yang menjadi pemuka dalam pembangunan desa.

\section{Kebersamaan (Betweeneess)}

Kebersamaan merupakan pengukuran sentralitas yang mengukur sejauh mana individu tertentu terletak di antara individu-individu lain dalam suatu jaringan. Menurut Freeman (1978) konsep kebersamaan mengacu pada tingkat frekuensi seorang individu yang berada di antara individu-individu yang berhubungan dalam suatu jalur komunikasi. Jika seseorang berada dalam suatu jalur komunikasi yang menghubungkan antar individu atau klik maka individu tersebut memiliki posisi yang sentral. Individu dengan nilai kebersamaan tinggi mempunyai potensi kendali komunikasi dalam suatu jaringan. Individu lain akan menjadi tergantung kepadanya jika jalur yang menghubungkannya dengan orang lain harus melewati individu tersebut.

Pada jaringan komunikasi internal Muhammadiyah Plompong, ketua ranting dan pimpinan lembaga-lembaga pendidikan Muhammadiyah serta lembaga da'wah 
Muhammadiyah menjadi individu-individu yang berada pada posisi kebersamaan dengan nilai maksimum. Sebab komunikasi di antara mereka sangat intens dan masalah-masalah yang menjadi topik pembicaraan juga sangat bervariasi, antara lain masalah kebijakan sekolah, kurikulum Al Islam dan Keorganisasi subyekan (AIKA) serta penerapan keputusan tarjih. Sedangkan, pada jaringan komunikasi eksternal, ketua ranting Organisasi subyek, ketua NU dan Kepala Desa Plompong merupakan individu-individu yang berada pada posisi kebersamaan dengan nilai maksimum. Posisi ketiganya terhadap komunikasi di internal organisasi masingmasing memiliki nilai kebersamaan yang tinggi dan menjadi sangat kuat karena mampu menyambungkan antar individu dalam sistem jaringan komunikasi di kelompoknya dan memiliki banyak hubungan dengan sumber informasi dari luar. Semua anggota sistem harus melalui mereka ketika akan berkomunikasi dengan anggota di sistem lain. Keadaan ini menyebabkan mereka banyak dihubungi dan posisinya menjadi konektor atau penghubung antar individu dalam jaringan komunikasi Muhammadiyah Plompong.

\section{Keterhubungan}

Hubungan (connectedness) adalah derajat di mana anggota-anggota sistem berhubungan dengan anggota-anggota lain dalam sistem. Nilai connectedness diukur dengan membandingkan semua ikatan yang sedang terbentuk dengan kemungkinan hubungan yang mungkin terjadi. Jika ada berbagai jalur yang berbeda yang menghubungkan dua individu, maka mereka memiliki "konektivitas" yang tinggi, dalam arti bahwa ada beberapa cara untuk mencapai individu yang lain. Konektivitas dapat menjadi ukuran yang berguna untuk mendapatkan pengertian tentang ketergantungan dan kerentanan individu (Hanneman \& Riddle 2005). Artinya, individu yang memiliki nilai keterhubungan maksimum berarti individu tersebut adalah individu yang paling berpengaruh, yaitu yang paling banyak memiliki hubungan dengan individu lain dalam sistem. Individu yang memiliki nilai minimum adalah individu yang paling sedikit memiliki hubungan dengan individu lain dalam sistem.

Dengan menggunakan software Ucinet 6, sebagaimana hasilnya tergambar pada sosiogram-sosiogram di atas, maka dapat diketahui bahwa para ketua Ranting Muhammadiyah Plompong, Kepala Desa Plompong, dan Ketua NU Plompong adalah individu-individu yang paling memegang peranan dalam jaringan komunikasi Muhammadiya Plompong. Mereka menjadi sangat kuat karena memiliki peran dominan dalam klik masing-masing pada jaringan komunikasi. Individu-individu yang paling sedikit memiliki hubungan dalam jaringan komunikasi Muhammadiyah Plompong, adalah para anggota pengurus Muhammadiyah yang dari sudut keaktifan kurang terlihat. Unsur terakhir itu, jarang terlibat dalam komunikasi, baik dalam pemberian gagasan, saran, maupun kritik. Mereka terlibat jika ada acara-acara seremonial organisasi saja.

\section{Deskripsi Jaringan Komunikasi di Ranting Muhammadiyah Plompong}

Dari hasil penelitian, pada dasarnya proses komunikasi yang terjalin di antara anggota sistem jaringan komunikasi Muhammadiyah Plompong, disebabkan oleh kedekatan tempat tinggal, emosional, dan kepentingan bersama. Kesemua anggota cenderung berkomunikasi dengan orang atau pihakpihak yang dinilai memiliki informasi yang dibutuhkan, mudah untuk diakses secara fisik disertai adanya keterbukaan. Pemilihan sumber informasi yang berada di eksternal organisasi dipilih berdasarkan kepentingan tertentu, kemudahan akses sumber informasi dan atas dasar kepercayaan serta kemampuan sumber informasi dalam memberikan informasi yang relevan.

Dinamika jaringan komunikasi Muhammadiyah Plompong, intensitasnya berjalan secara bertahap. Sesuai dengan hasil penelitian, jaringan komunikasi yang kondusif baru tercipta sejak periode 
kebangkitan (1981-1990) sampai periode sekarang. Hasilnya antara lain dapat memperkuat konsolidasi organisasi dan kerjasama dengan pihak-pihak luar, pemerintahan, dan organisasi-organisasi masyarakat lainnya. Pada periode sebelumnya, jaringan komunikasi Muhammadiyah ditujukan hanya untuk menyelesaikan konflik horizontal dan memperkuat kedudukan organisasi sesuai peraturan yang berlaku.

Dari gambaran-gambaran yang dihasilkan, jaringan komunikasi pada konteks Muhammadiyah Plompong terlihat sebagai struktur jaringan komunikasi yang bersifat personal memusat (interlocking personal network). Pemusatan juga terjadi di setiap klik, di mana individu anggota klik cenderung berkomunikasi pada satu individu. Rogers dan Kincaid (1981) menyatakan, jaringan personal yang memusat (interlocking) mempunyai derajat integrasi yang tinggi.

\section{KESIMPULAN DAN IMPLIKASI}

1. Pimpinan Ranting Muhammadiyah Desa Plompong membentuk jaringan komunikasi sebagai upaya mendesiminasi informasi eksistensi persyarikatan dan amal-amal usahanya.

2. Analisis terhadap jaringan komunikasi menghasilkan sosiogram yang menggambarkan struktur komunikasi yang terjalin di lingkungan komunikasi Ranting Muhammadiyah Plompong. Selain itu, memperlihatkan gambaran siapa saja yang terjangkau oleh informasi, bagaimana informasi terdistribusi ke semua anggota sistem, struktur jaringan komunikasi yang terbentuk serta bagaimana peran dari aktor-aktor dalam struktur jaringan komunikasi tersebut.

3. Sentralitas lokal menunjukkan ketua ranting sebagai individu yang paling banyak menjadi sumber informasi. Ia juga berperanan dalam sentralitas global, karena memiliki akses yang lebih luas untuk berhubungan dengan aparat pemerintahan, dan pimpinan organisasi masyarakat lainnya di Desa Plompong.

4. Pada sentralitas global selain ketua ranting yang paling banyak menjadi sumber informasi dalam sistem jaringan komunikasi Muhammadiyah Plompong, posisi itu diisi pula oleh Kepala Desa Plompong, dan Ketua NU Plompong. Ketiga individu menjadi leader dalam kliknya masing-masing.

5. Densitas jaringan menunjukkan hampir semua anggota dalam sistem jaringan komunikasi Muhammadiyah Plompong memiliki kesempatan menghubungi sumber informasi atau memiliki kecepatan informasi yang relatif tinggi.

\section{DAFTAR PUSTAKA}

Freeman LC. 1978. Centrality in social networks: Conceptual clarification. Social Networks. 1: 215-239.

Hanneman, R.A., Riddle, M. (2005). Introduction to Social Network Methods. Riverside, CA: University of California, Riverside, Online textbook, diakses 4 Desember 2011, dari http://faculty.ucr.edu/ hanneman/nette $\mathrm{xt} /$.

Harris TE, Nelson MD. 2008. Applied Organizational Communication. Theory and Practice in A Global Environment. New York (US): Lawrence Erlbaum Associates.

Hatala J. 2006. Social network analysis in human resource development: A new methodology. Human Reource Deevelopment Review. 5 (1): 121-134

Monge PR, Contractor NS 2003. Theories of Communication Networks. New York (US): Oxford University Press.

Scott J. 2000. Social Network Analysis: A Handbook. Second Edition. California (US): Sage Publication Inc.

Todo Y, Yatade DM, Matous P, Takahashi R. 2011. Effects of geography and social networks on diffusion and adoption of agricultural technology: Evidence from 
Rural Ethiopia. Paper Konferensi Valente TW, Foreman RK. 1998. Integration International Sains Terapan Daerah Kyoto University Jepang (JP), February. 1-28. and radiality: Measuring the extent of an individual's connectedness and Rogers EM, Kincaid DL. 1981. Comunnication Networks. Toward a New Paradigm for Research. New York (US): A reachability in a network. Social Networks. 20 (1): 89-105.

Division of Macmillan Publishing Co. Inc. 